\title{
Estimation of the long-term cyclical fluctuations of snow-rain floods in the Danube basin within Ukraine
}

\author{
Tetiana Zabolotnia, Liudmyla Gorbachova, Borys Khrystiuk \\ Ukrainian Hydrometeorological Institute, Prospekt Nauki 37,03028 Kyiv, Ukraine, e-mail: tzabolotnia@gmail.com, \\ gorbachova@uhmi.org.ua,khryst@uhmi.org.ua
}

\begin{abstract}
Floods are a periodic natural phenomenon, often accompanied by negative consequences for the local population and the economy as a whole. Therefore, knowledge of the trends of maximum flow have great practical importance, because it is the basis for planning and designing various hydraulic structures, hydrological forecasting, the mapping of flood risk, etc. In this paper, we analysed the long-term cyclical fluctuations of the maximum flow of snow-rain floods of the Danube basin within Ukraine (5 large rivers, 14 medium and 5 small). The database includes time series (34 gauging stations) of the maximum discharges of the cold period from the beginning of the observations up to 2015. The methodological approaches (developed by Gorbachova) are based on the use of hydro-genetic methods - namely the mass curve, the residual mass curve, and combined graphs. The presented results illustrate that the longterm fluctuations of the maximum flow of snow-rain floods are synchronous at all study gauging stations in the Danube basin within Ukraine, but these fluctuations are not always in the synchronous phase. We found that the maximum flow of snow-rain floods in the Danube basin within Ukraine have four types of long-term fluctuations, each with a different cycle duration.
\end{abstract}

Keywords: cyclical fluctuations, stationarity, homogeneity, snow-rain flood, synchronicity, mountain rivers

Submitted 13 December 2017, revised 24 April 2018, accepted 14 November 2018

\section{Introduction}

The long-term cyclicality fluctuations of streamflow mean that there are instabilities in the streamflow, characterised by alternating wet and dry phases of different durations and different degrees of deviation from the mean of the long-term flow for the review period (Pekarova et al. 2003). The periods of wet years change to dry, and vice versa. In closely located river basins, under the same climatic conditions and similar elements of the geographical landscape, the streamflow fluctuations are usually synchronous. However, as was found in our previous studies (Gorbachova, Bauzha 2012, 2013; Gorbachova, Khrystyuk 2014; Bauzha, Gorbachova 2017), in the case of the synchronous fluctuations of flow, it is often observed that there is asynchronicity in the phase of fluctuations in the various hydrological stations within the same basin.

In the study of the spatio-temporal fluctuations of water flow, a variety of methods are used. Both statistical and genetic methods are more commonly used (WMO 2009). Among the statistical methods, the most frequently used are correlation, regression, cluster, dispersion, and spectral analysis. The genetic method consists of the graphic methods that mainly include various correlation graphs, frequency of values, histograms, mass curves, double mass curves, residual mass curves, chronological charts, and others (Chow et al. 1988). The methodical approaches to using these methods were developed by Rippl (1883), Merriam (1937), Searcy and Hardison (1960), and others. The guidelines for these methods were developed separately for each method and for solving particular problems. However, with certain graphic (hydro-genetic) methods, we can successfully carry out the assessment of the spatio-temporal fluctuations of runoff. Therefore, in this paper, the methodological approaches for the hydro-genetic methods are used. This approach was developed by Gorbachova (2014, 2015).

In this paper, the maximum flow of the cold period of the Danube River basin (Ukrainian part) was investigated. The study of the current spatio-temporal fluctuations in the dangerous phase of the hydrological regime of this river is our actual task, because snow-rain floods of varying heights repeat 3-8 times a year in the mountain rivers of the Danube basin within Ukraine. These floods are especially dangerous in the wet phase that is caused by global atmospheric circulation. In the wet phase, significant floods are observed predominantly with 3-4 and 6-8 year recurrence intervals. At the same time, Central and Western Europe also suffer from these natural disasters (Susidko, Luk'yanets 2009; Pekarova et al. 2014). Thus, such studies are important for hydrological and water 
management calculations. The goal of this paper is the study of the long-term cyclicality fluctuations of maximum flow of the snow-rain floods of the Danube basin within Ukraine based on the use of hydro-genetic methods. The main tasks of the research are as follows:

- assessment of the spatio-temporal fluctuations of the maximum flow of the snow-rain floods of the Danube Basin within Ukraine;

- analysis of the phases of cyclical fluctuations of the maximum discharges;

- assessment of the stationarity of the observation series with residual mass curves;

- estimation of the homogeneity of the observation series with the mass curves;

- analysis of the largest and smallest maximum discharge of the snow-rain floods of the Danube basin within Ukraine for a long-term period.

\section{The study area}

The Danube River is the second largest water course in Europe (after the Volga River), with a total catchment area of $817000 \mathrm{~km}^{2}$. It is the world's most international river basin and includes the territories of 19 countries (including Romania, Hungary, Austria, Serbia, Germany, Slovakia, and Bulgaria) (Pekarova et al. 2003). The river originates in the central-western part of Europe (Schwarzwald), runs through the central part of the continent, crosses the Pannonian Depression to the confluence with the Drava, then pierces the Carpathian Mountains through the Iron Gate Gorge. Farther down, it separates the southern part of the Romanian Plain from the Prebalkan Tableland, and the eastern part of the Plain from the Dobrogea Plateau and Mountains. The last sector of the river, up to the Black Sea, encompasses the Delta area (Gastescu, Tuchiu 2012). The Danube River has a total length of $2857 \mathrm{~km}$,
Table 1. Characteristics of rivers of the Danube River Basin

\begin{tabular}{|l|c|c|}
\hline Name of river & $\begin{array}{c}\text { Catchment area } \\
{\left[\mathrm{km}^{2}\right]}\end{array}$ & $\begin{array}{c}\text { Catchment area }\left[\mathrm{km}^{2}\right] \\
\text { (within Ukraine) }\end{array}$ \\
\hline Danube & 817000 & 32350 \\
\hline Tysa & 153000 & 11300 \\
\hline Siret & 47600 & 2070 \\
\hline Prut & 27500 & 17400 \\
\hline Latorytsya & 7680 & 4900 \\
\hline Uzh & 2750 & 2010 \\
\hline
\end{tabular}

and approximately one third of its basin is mountainous. The Danube Basin can be subdivided into three main parts (the Upper, Central and Lower Danube regions), in addition to the Danube delta (Pekarova et al. 2014). Within Ukraine, the Danube River flows only in its lower part, with a length of $174 \mathrm{~km}$ ( $6 \%$ of the total length), and the catchment area is $32350 \mathrm{~km}^{2}$ (Table 1). It occupies the southern and southeastern slopes of the Eastern Carpathians, Transcarpathia, and the southwestern outskirts of the Black Sea Lowland.

In this paper, the main rivers and their tributaries in the Danube Basin within Ukraine are investigated (Fig. 1). These are 5 large rivers (Tysa, Prut, Latorytsya, Uzh, and Cheremosh) $\left(F_{\text {basin }}=1000-10000 \mathrm{~km}^{2}\right)$, 14 medium rivers (Siret, Chornyi Cheremosh, Teresva, Bilyi Cheremosh, Rika, Putyla, Turia, Borzhava, Chorniava, Vicha, Stara, Chorna Tysa, Bila Tysa, and Kosivska) $\left(F_{\text {basin }}=100-1000 \mathrm{~km}^{2}\right)$, and 5 small rivers (Iltsia, Holiatynka, Pylypets, Studenyi, and Kamianka) $\left(F_{\text {basin }}=\right.$ $10-100 \mathrm{~km}^{2}$ ) according to the classification of the EU Water Framework Directive (2000/60/EC). Such a classification was carried out according to the area of the catchment of the river from river springs to locking post within Ukraine.

The Tysa River Basin is the largest sub-basin in the Danube Basin (Table 1). It is also the Danube's longest tributary $(966 \mathrm{~km})$. In the territory of Ukraine, there is the upper, mostly right bank part of the Tysa basin.

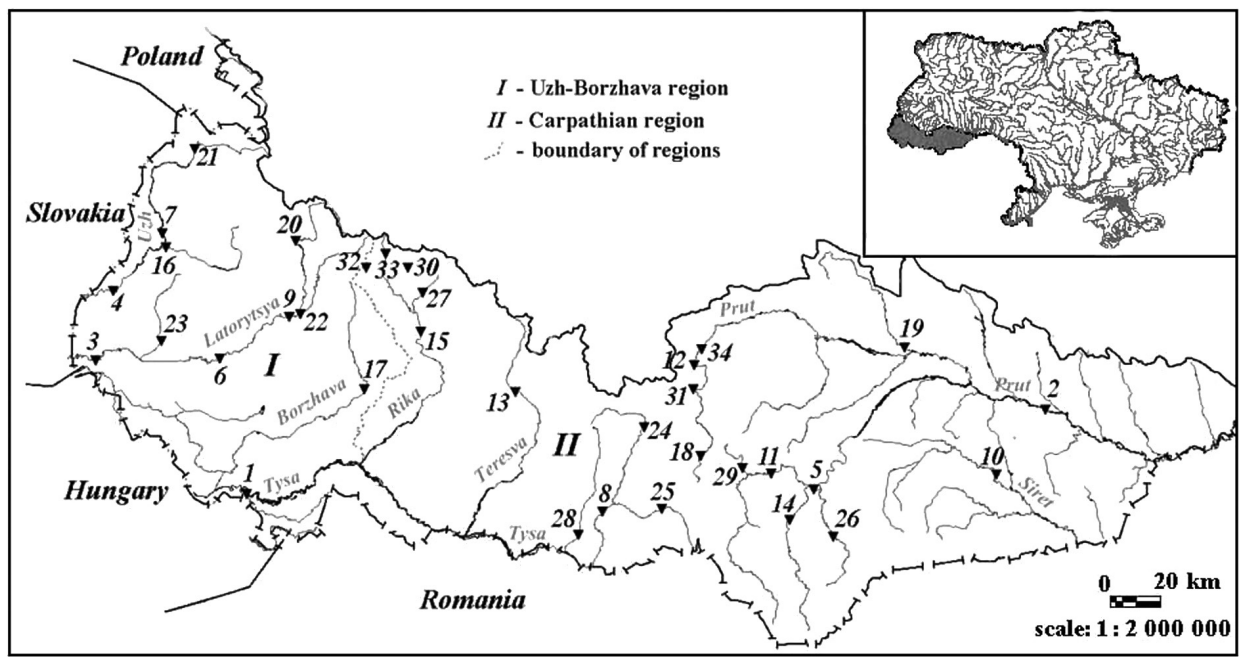

Fig. 1. Location of the 34 water gauges in the Danube basin within Ukraine (the numbering of stations is based on Table 2) 
The river at the upper part is a typical mountain river. It has a narrow valley, and it sometimes looks like a gorge with relatively steep slopes. The right bank tributaries of the Tysa River cover the southern slope of the Ukrainian Carpathians. The average altitudes of these catchments within the mountains are 800-1200 m, and the average slopes are $200-400 \mathrm{~m} / \mathrm{km}$. The long-term average water discharge near Vylok village is $207 \mathrm{~m}^{3} \mathrm{~s}^{-1}$ (1954-2013).

The Prut River is a left tributary of the Danube (Table 1). The river springs from the northeastern slope of the Chornohora Massif at an altitude of approximately $1600 \mathrm{~m}$. The basin of the Prut River, being a transboundary basin, is located in the territory of three countries (Moldova, Ukraine, and Romania). The average slope of the catchment in the upper reaches is $285 \mathrm{~m} / \mathrm{km}$, whereas it is much smaller in the lower reaches. The average meandering ratio is 2.1. The largest tributary of the Prut River is the Cheremosh River. The long-term average water discharge near Chernivtsi city is $67.7 \mathrm{~m}^{3} \mathrm{~s}^{-1}(1945-2013)$.

The Siret River is a left tributary of the Danube, starting from the confluence of the Bursuky and Lustun mountain sources next to Dolyshni Shepit village in Chernivtsi Oblast (Table 1). In its upper section (to the Beregomet settlement), it is a typical mountain river, but downstream it gains submountain and lowland features with a wide valley, which is swampy in some places. The Siret flows into the Black Sea. In the upper part, it flows through the territory of Ukraine $(110 \mathrm{~km})$ and then Romania (596 km). The general fall is $435 \mathrm{~m}$. The slope of the river is $4.4 \mathrm{~m} / \mathrm{km}$. The meandering ratio is 1.92 . The long-term average water discharge near Storozhynets town is $6.63 \mathrm{~m}^{3} \mathrm{~s}^{-1}$ (1953-2013).

The Latorytsya River is a left tributary of the Bodrog River (tributary of the Tysa River) (Table 1). The river springs from the Ukrainian Carpathians (Eastern Carpathian Mountains) near the village Latorka. It flows from Ukraine $(156.6 \mathrm{~km})$ to Slovakia $(31.4 \mathrm{~km})$. Its slope varies from $80 \mathrm{~m} / \mathrm{km}$ in the upper reaches to $0.2 \mathrm{~m} / \mathrm{km}$ in the lower reaches. The long-term average water discharge near Chop town is $35.9 \mathrm{~m}^{3} \mathrm{~s}^{-1}$ (1957-2013).

The Uzh River is a left tributary of the Laborec River (tributary of the Latorytsya River) (Table 1). The river springs in the mountains in the northwest of Transcarpathia. It flows from Ukraine $(107 \mathrm{~km})$ to Slovakia $(26 \mathrm{~km})$. The slope of the river is $7.2 \mathrm{~m} / \mathrm{km}$. The long-term average water discharge near Uzhhorod city is $29.3 \mathrm{~m}^{3} \mathrm{~s}^{-1}$ (1947-2013).

The temperature regime in the Danube basin is determined mainly by the nature of the circulation of air masses and the features of the terrain. The long-term average annual air temperature within the Ukrainian part of the basin is $8.1^{\circ} \mathrm{C}$ for the Chernivtsi weather station and $9.6^{\circ} \mathrm{C}$ for the Uzhhorod weather station. The coldest month is January, with average temperatures ranging from -0.3 to $-3^{\circ} \mathrm{C}$ in the lowlands and -8 to $-9^{\circ} \mathrm{C}$ at the highest points, and in some places even lower. In July, the average air temperatures rise to $17-24^{\circ} \mathrm{C}$ (Pekarova et al. 2014). The long-term annual average precipitation total at the Uzhhorod weather station is $785 \mathrm{~mm}$, and it is $652 \mathrm{~mm}$ at the Chernivtsi weather station.

The Ukrainian Carpathians are characterised by significant heterogeneity of the territory, which results in different conditions of flow formation. Thaws are observed in the mountain rivers of the Carpathians due to the unstable thermal regime and frequent transitions in the winter period from negative to positive air temperatures in December to February. During these thaws, a flow of mixed origin (from the melting of snow and liquid precipitation) is formed. In this case, high floods occur, which are characterised by the highest water discharges per year in the long-term period. Sometimes, such floods become catastrophic and threaten not only the economy of the region but also human life. The Carpathians are the region with the most danger of flooding in all of Ukraine (Susidko, Luk'yanets 2009).

According to hydrological regionalisation by the intraannual distribution of the flow, the Tysa, Prut and Siret Rivers within Ukraine belong to two hydrological regions, namely the Uzh-Borzhava and Carpathian regions (Gorbachova 2015). For the rivers of the Carpathian region (the upper reaches of the Tysa River to the Rika River, including the Prut and Siret rivers), the wet period lasts from March to July, the autumn period is characterised by floods, and winter is characterised by the smallest discharges in the year. The rivers of the Uzh-Borzhava region are characterised by intense floods in the cold period of the year. Thus, the lowest discharges are observed from August to October.

\section{Methodology and data}

Available and reliable flood observation data help to improve understanding of flood processes and associated changes in flood characteristics and regimes (Hall et al. 2015). The analysis of the cyclicality of water flow depends on the availability of long-term observation data. The longer the duration of the observation series, the more it is possible to reliably determine the decrease and increase in the phases of cyclic fluctuations of water flow for each river.

This study of the long-term fluctuations of the maximum flow of snow-rain floods is conducted at 34 gauging 
Table 2. List of selected water gauges along the Danube River Basin within Ukraine

\begin{tabular}{|c|c|c|c|c|}
\hline No. & River & Water gauge & $\begin{array}{c}\text { Catchment area } \\
{\left[\mathrm{km}^{2}\right]}\end{array}$ & Study period \\
\hline 1 & Tysa & Vylok village & 9140 & $1954-2015$ \\
\hline 2 & Prut & Chernivtsi city & 6890 & $\begin{array}{l}1895-1911,1919-1924, \\
1926-1935,1945-2015\end{array}$ \\
\hline 3 & Latorytsya & Chop town & 2870 & $1957-2015$ \\
\hline 4 & Uzh & Uzhhorod city & 1970 & $1947-2015$ \\
\hline 5 & Cheremosh & Usteriky village & 1500 & $1958-2015$ \\
\hline 6 & Latorytsya & Mukachevo town & 1360 & $1947-2015$ \\
\hline 7 & Uzh & Zaricheve village & 1280 & $1947-2015$ \\
\hline 8 & Tysa & Rahiv city & 1070 & $1947-2015$ \\
\hline 9 & Latorytsya & Svaliava town & 680 & $1962-2015$ \\
\hline 10 & Siret & Storozhynets town & 672 & $1953-2015$ \\
\hline 11 & $\begin{array}{l}\text { Chornyi } \\
\text { Cheremosh }\end{array}$ & Verhovyna village & 657 & $1958-2015$ \\
\hline 12 & Prut & Yaremche town & 597 & $1950-2015$ \\
\hline 13 & Teresva & Ust-Chorna village & 572 & $\begin{array}{c}\text { 1949-1976, 1978-1982, } \\
1986-2015\end{array}$ \\
\hline 14 & $\begin{array}{l}\text { Bilyi } \\
\text { Cheremosh }\end{array}$ & Yablunytsia village & 552 & $1958-2015$ \\
\hline 15 & Rika & Mizhhiria village & 550 & $1946-2015$ \\
\hline 16 & Turia & Simer village & 464 & $1958-2015$ \\
\hline 17 & Borzhava & Dovhe village & 408 & $1947-2015$ \\
\hline 18 & Prut & Tatariv village & 366 & 1959-2015 \\
\hline 19 & Chorniava & Lyubkivtsi village & 333 & $\begin{array}{c}1985-1989, \\
1991,1993-1997, \\
1999-2007,2009-2015\end{array}$ \\
\hline 20 & Latorytsya & Pidpolozzia village & 324 & $1947-2015$ \\
\hline 21 & Uzh & Zhornava village & 286 & $1952-2015$ \\
\hline 22 & Vicha & Nelipyne village & 241 & $1958-2015$ \\
\hline 23 & Stara & Zniatseve village & 224 & $1952-2015$ \\
\hline 24 & $\begin{array}{l}\text { Chorna } \\
\text { Tysa }\end{array}$ & Yasinia village & 194 & $1956-2015$ \\
\hline 25 & Bila Tysa & Luhy village & 189 & $1955-2015$ \\
\hline 26 & Putyla & Putyla village & 181 & $\begin{array}{l}1963-1993, \\
1996-2015\end{array}$ \\
\hline 27 & Rika & Verhnii Bystryi village & 165 & $\begin{array}{l}\text { 1954-1994, } \\
1999-2015\end{array}$ \\
\hline 28 & Kosivska & Kosivska Poliana village & 122 & $1963-2015$ \\
\hline 29 & Iltsia & Iltsi village & 86.1 & $1959-2015$ \\
\hline 30 & Holiatynka & Maidan village & 86 & $\begin{array}{l}\text { 1956-1994, } \\
1999-2015\end{array}$ \\
\hline 31 & Prut & Vorohta village & 48.3 & $1978-2015$ \\
\hline 32 & Pylypets & Pylypets village & 44.2 & $1956-2015$ \\
\hline 33 & Studenyi & Nyzhnii Studenyi village & 25.4 & $\begin{array}{l}1954-1994, \\
1999-2015 \\
\end{array}$ \\
\hline 34 & Kamianka & Dora village & 18.1 & $1946-2015$ \\
\hline
\end{tabular}

stations situated in the Danube River basin within Ukraine. The maximum discharges in the cold period are analysed in the study. The cold period is characterized by a steady decrease in air temperature below $0^{\circ} \mathrm{C}$. During this period, the floods are of mixed origin, namely snow-rain (Kosovets et al. 2005). The maximum discharge data of the cold period are obtained from the archive of the Central Geophysical Observatory of Ukraine. The analyses are carried out for the data series at all stations from the beginning of the observations to 2015 inclusive. The period of observation of these water bodies is from 27 (Chorniava River - Liubkivtsi village) to 104 (Prut River - Chernivtsi city) years (Table 2).

In terms of the hydro-genetic analysis, including concepts such as change and variability, the homogeneity and stationarity of the hydrological series were defined. 
The homogeneity of the time series is the absence of unidirectional changes of the hydrological characteristic (this refers to one genetic series: floods, rain floods, etc.) over time against the backdrop of its variability due to long-term cyclical fluctuations. The stationarity of the time series is the constancy of average value hydrological characteristic over time if the time series has at least one full closed cycle (dry and wet phase) of long-period fluctuations. The change of the time series is the unilateral deviation from a straight line of the hydrological characteristic, which is in such a state that the hydrological characteristic moves to a new quality, due to the state of factors that are formed by the hydrological characteristic or human activities. The variability of the time series is a temporary deviation from a straight line of the hydrological characteristic that is in such a state that the hydrological characteristic acquires a new quality only for a period. In the case of long-term cyclical fluctuations, this period can last for decades; but at the same time, the hydrological characteristic from time to time returns to its "old" state. This same scenario is relevant for shortterm cyclical fluctuations, but the period is much shorter and is usually considered to be a few years.

The assessment of the homogeneity and stationarity of the hydrological series necessitated the following:

- In the hydrological series, there is a need to restore the gaps in observations and bring them to a long time period, thus allowing the tracing of the temporal dynamics of hydrological characteristics over a longer time interval.

- The homogeneity of the hydrological characteristic over time is researched with a mass curve.

- The stationarity of the hydrological characteristic is researched with a residual mass curve.

To clarify the results obtained (if necessary), other hydro-genetic methods and approaches can be used (the analysis of meteorological factors of the runoff formation, the combined graphics, etc.)

For the assessment of the homogeneity of the observation series, the mass curve was used. In 1883 Rippl developed the mass curve and the residual mass curve methods. Now, the mass curve is used to detect the influence of anthropogenic factors (hydraulic structures, canals) and of climate change (the presence of trends in the data series). If "jumping" on the mass curve is not found, and neither are "emissions" or unidirectional deviation, then the generation of runoff in the study area is homogeneous, and vice versa. The mass curve is defined with the following formula:

$$
W=\sum_{t=1}^{T} w(t)
$$

where: $W$ - the total runoff of the river for time period $T$; $w(t)$ - the runoff of th year.

For the assessment of the spatio-temporal fluctuations of the maximum flow of the snow-rain floods of the Danube basin within Ukraine, the residual mass curve and combined graphs were used. The analysis of the residual mass curve allows the definition of the stationarity of data series, namely the sustainability of the average value of the hydrological characteristic in the course of time. The average value of the time series is stable in the presence of at least one full closed cycle (dry and wet phase) of long-period fluctuations. The residual mass curve is defined according to (Andreyanov 1959):

$$
f(t)=\frac{\sum_{t=1}^{T}(k(t)-1)}{C_{v}}
$$

where: $C_{v}$ - the variation coefficients of runoff; $k(t)=Q(t) / Q_{0}$ - the modulus coefficients; $Q(t)$ and $Q_{0}$ - the discharge of the $t^{\text {th }}$ year and the average discharge for the period of time $T$.

According to Andreyanov's formula (2), the dry and wet phases were identified. The wet phase is characterized by an increasing tendency, and the dry phase is characterized by a decreasing tendency.

Combined graphs of characteristics allow the definition of the synchrony/asynchrony of long-term fluctuations in different rivers within the one hydrologically homogeneous area. In turn, the synchronous fluctuations are indicated on the homogeneous climatic conditions for the formation of runoff.

\section{Results}

Graphs of the mass curves and residual mass curves of the maximum flow of the snow-rain floods in the Danube Basin within Ukraine were created for 34 catchments.

The analysis of these graphs shows that the series of observations are homogeneous, because no significant points of fracture in direction ("jumpings" or unidirectional deviation) were found on any mass curves (Gorbachova, Bauzha 2012, 2013; Bauzha, Gorbachova 2017). Examples of such curves are shown in Figure 2.

Some of these may raise doubts about the homogeneity of the hydrologic characteristics, e.g., the observation series in Figure 2c. However, the shape of the sum curve is determined by the structure of the observation series, namely the presence of only phases of prolonged increase and decrease in the cyclical fluctuations (Fig. 3). 
a) TYSA RIVER - Vylok village

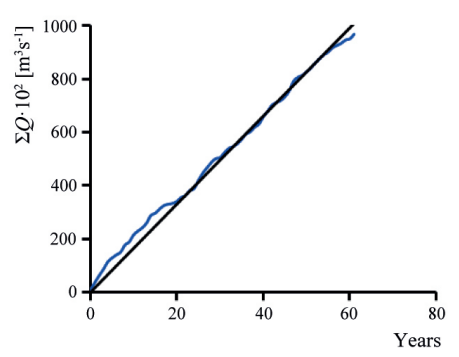

c) UZH RIVER - Uzhhorod city

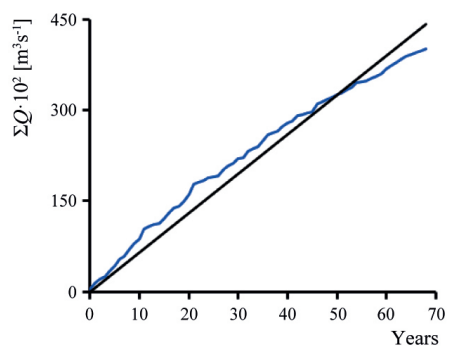

b) SIRET RIVER - Storozhynets town

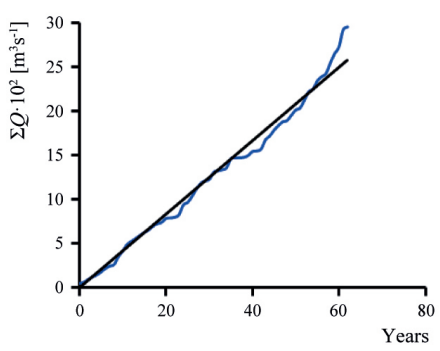

d) PRUT RIVER - Chernivtsi city

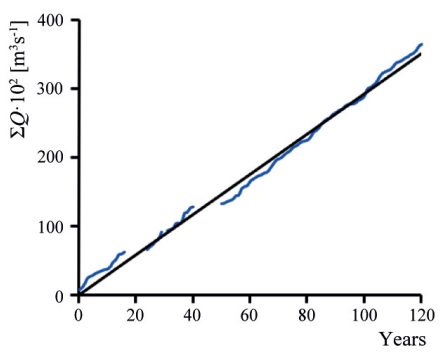

Fig. 2. Some mass curves of the maximum flow of snow-rain floods in the Danube River basin within Ukraine

Such a situation is temporary. With the extension of the duration of observations, the data series will have several phases of cyclical fluctuations. For example, the mass curve looks similar to that in Figure $2 \mathrm{~d}$ for the gauging station Prut River - Chernivtsi city. The observation series at the gauging station Prut river - Chernivtsi city is the longest and has several decreasing and increasing phases of long-term cyclical fluctuations. The durations of full cycles are approximately 15-20 years (Fig. 3). Therefore, the observation series of the maximum flow of snow-rain floods in the Danube Basin within Ukraine are homogeneous and quasi-homogeneous.

An analysis of the stationarity of the maximum flow of snow-rain floods of the Danube River Basin and its cyclical fluctuations was carried out using the residual mass curves of the data series of 34 gauging stations. According to the analysis, these curves have similar and distinctive features in their configuration. The longterm fluctuations of the maximum flow at all gauging stations are synchronous, but they are not always in synchronous phase (Fig. 4).

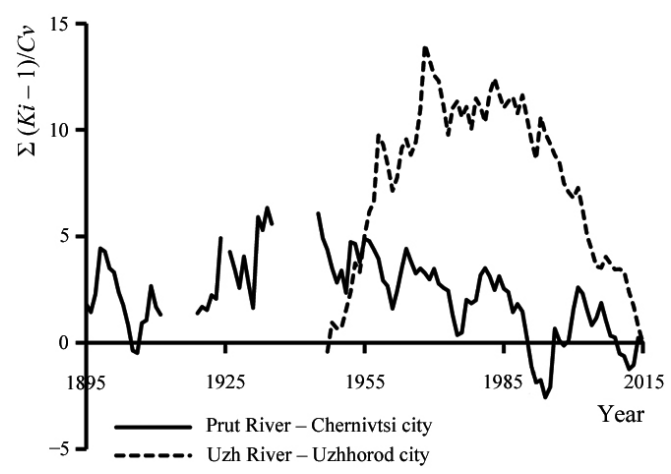

Fig. 3. The residual mass curves of the maximum flow of snowrain floods in the Danube River basin within Ukraine
Thus, several types of cyclical fluctuations were identified (Fig. 5). The first type of long-term cyclical fluctuations includes the observations series that have only two phases: decreasing and increasing. Such fluctuations in the maximum flow of snow-rain floods are characteristic of the Uzh River. The increase phase began from the beginning of the observation and continued until 1968. The decrease phase began after 1968 and continues to this day (Fig. 5a). For some rivers in other basins, which can also be attributed to the first type of fluctuation (e.g., the Holyatynka river - Maidan village, and the Turia River - Simer village), the increasing phase continued until 1989 (Fig. 5a).

The second type of cyclical fluctuation includes the observation series, which are characterized by an increasing phase from the beginning of the observations to the end of the 1960s. After this, such phases changed to the decreasing

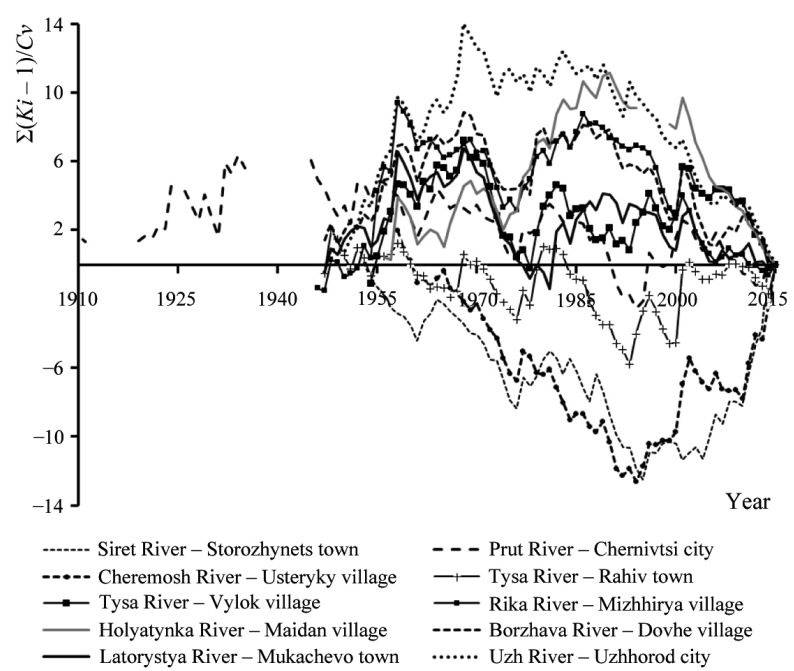

Fig. 4. Some residual mass curves of the maximum flow of snowrain floods in the Danube River Basin within Ukraine 

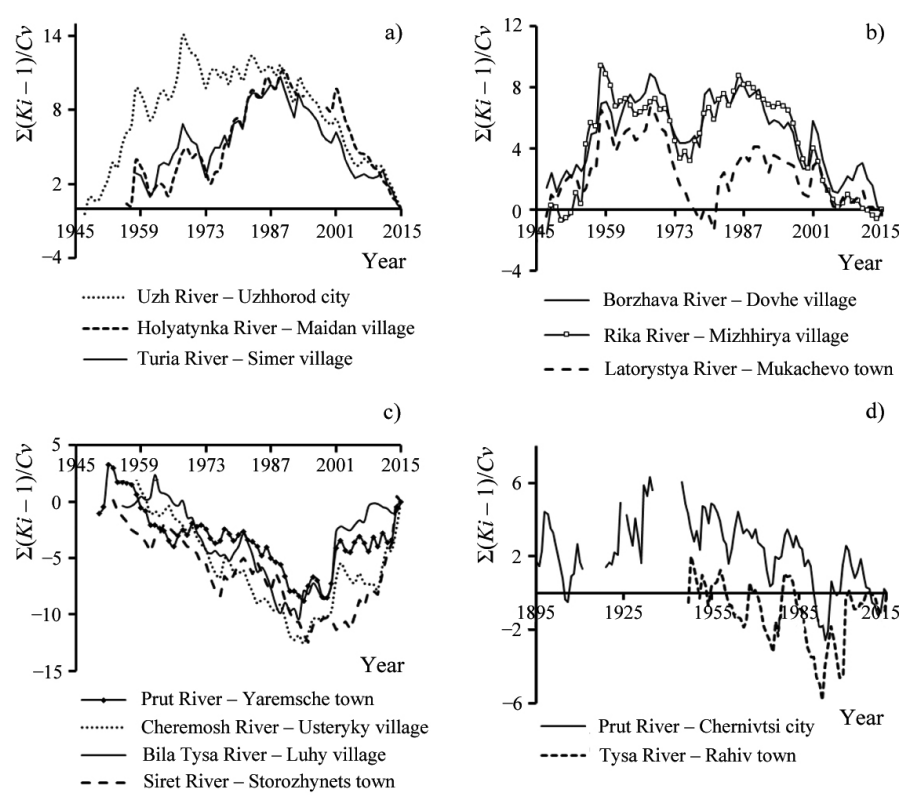

Fig. 5. Types of long-term cyclic fluctuations of the maximum flow of snow-rain floods in the Danube River Basin within Ukraine

phase, which continued until the mid-1970s. The increasing phase began again after the 1970s and continued until the mid1980s, and it has since then changed to the decreasing phase of cyclical fluctuations. This type of fluctuation is seen in such rivers as Latorytsya, Borzhava, and Rika (Fig. 5b).

The third type of fluctuations includes the rivers that, from the beginning of the observation and until the mid1990s, are characterized by the decreasing phase. After this, the phase changed to the increasing phase, with minor variations in some years. This type of fluctuation is seen in the rivers Upper Tysa, Siret and Upper Prut (Fig. 5c).

The fourth type of fluctuations includes the rivers Tysa and Prut, which have cyclic fluctuations of 15-20 year duration. On Figure 5d, it is seen that the long-term cyclical fluctuations at the gauging stations Tysa River - Vylok village and Prut River - Chernivtsi city have synchronous and in-phase fluctuations.

Generally, the observation series of the maximum flow of snow-rain floods in the Danube Basin within Ukraine are characterised by synchronous fluctuations, which do not always have synchronous phases. It can be assumed that the differences in cyclic fluctuations are caused by factors of the underlying surface of the river basins - namely:

1) The mountain relief, which is significantly cut by river valleys (defines peculiar patterns of runoff formation, which manifest in the uneven distribution of precipitation, temperature and humidity in the basin).

2) Exposure of slopes (the windward slopes receive considerably more rainfall).

3) The presence of large forest areas.

Table 3 provides information on the largest and smallest maximum discharge of the cold period of the year of the 34 water gauges along the Danube River Basin within Ukraine for long-term periods. During the study period, the largest values of the maximum discharge of snow-rain floods $\left(3580 \mathrm{~m}^{3} \mathrm{~s}^{-1}\right)$ were observed for the water gauges on the Tysa River - Vylok village in 2001. This value is 2.3 times higher than the long-term average of the maximum water discharge (1954-2015). It was the largest flood over the entire observation period (historical flood), and it had catastrophic consequences because it resulted in the loss of human lives and significant economic damage (Boiko, Kulbida 2001).

In general, the maximum runoff of the cold period over the past 10 years is characterised by a decreasing trend in most of the study gauges (Fig. 5a, b, d), with the exception of some hydrological stations (Siret River Storozhynets town, Cheremosh River - Usteriky village, Iltsia River - Iltsi village, Prut River - Yaremche town, Prut River - Tatariv village, Bila Tysa River - Luhy village, Chornyi Cheremosh - Verhovyna village, Putyla River - Putyla village, and Kamianka River - Dora village) (Fig. 5c).

\section{Conclusion}

The study presents results from time-series analyses using hydro-genetic methods for maximum discharges of snow-rain floods in the Danube Basin within Ukraine. The observation series of the maximum flow have different types of long-term cyclic fluctuations. In total, four types of fluctuations were determined, and they are conditioned by the climatic and the orographic features of the research area. Each type of cyclic fluctuation is characterised by a different duration. Only for the rivers Prut and Tysa can the duration of fluctuations be reliably 
Table 3. The largest and the smallest of the maximum discharge $\left[\mathrm{m}^{3} \mathrm{~s}^{-1}\right]$ of the cold period of the year of the Danube Basin within Ukraine for long-term periods

\begin{tabular}{|c|c|c|c|c|}
\hline \multirow[t]{2}{*}{ River } & \multirow[t]{2}{*}{ Water gauge } & \multirow[t]{2}{*}{$\begin{array}{c}Q_{\text {average }} \\
{\left[\mathrm{m}^{3} \mathrm{~s}^{-1}\right]}\end{array}$} & \multicolumn{2}{|c|}{$\begin{array}{c}Q_{\max .} \text { cold period } \\
{\left[\mathrm{m}^{3} \mathrm{~s}^{-1}\right]} \\
(\text { per year })\end{array}$} \\
\hline & & & $\max$ & $\min$ \\
\hline Tysa & Vylok village & 207 (1954-2013) & $3580(2001)$ & $302(1973)$ \\
\hline Tysa & Rahiv city & $25.6(1947-2013)$ & $938(2001)$ & $15.4(1987)$ \\
\hline Chorna Tysa & Yasinia village & $4.83(1956-2013)$ & $186(2001)$ & $5.50(1963)$ \\
\hline Bila Tysa & Luhy village & $5.11(1955-2013)$ & $84(2001)$ & $5.44(1969)$ \\
\hline Borzhava & Dovhe village & $11.0(1947-2013)$ & 411 (1979) & $26.4(1972)$ \\
\hline Kosivska & Kosivska Poliana village & $4.60(1963-2013)$ & $213(2001)$ & 4.48 (1984) \\
\hline Teresva & Ust-Chorna village & $18.3(1949-2013)$ & $665(2001)$ & $22.2(1963)$ \\
\hline Siret & Storozhynets town & $6.63(1953-2013)$ & $195(2014)$ & $2.69(1990)$ \\
\hline Prut & Chernivtsi city & $67.7(1945-2013)$ & $1316(1932)$ & $46.2(1990)$ \\
\hline Prut & Vorohta village & $1.98(1978-2013)$ & $82.6(2001)$ & $2.18(1991)$ \\
\hline Prut & Tatariv village & $8.01(1960-2013)$ & $126(2001)$ & $13(1991)$ \\
\hline Prut & Yaremche town & $12.6(1950-2013)$ & $299(1952)$ & $10.5(1998)$ \\
\hline Cheremosh & Usteriky village & $27.8(1958-2013)$ & $392(2001)$ & $26.3(1991)$ \\
\hline Bilyi Cheremosh & Yablunytsia village & $9.38(1958-2013)$ & $120(2001)$ & $8.85(1991)$ \\
\hline Chornyi Cheremosh & Verhovyna village & $14.1(1958-2013)$ & $219(2001)$ & $8.05(1991)$ \\
\hline Iltsia & Iltsi village & $1.66(1959-2013)$ & $51.2(2014)$ & $1.84(1991)$ \\
\hline Kamianka & Dora village & $0.36(1949-2013)$ & $22.6(2011)$ & $0.17(1946)$ \\
\hline Putyla & Putyla village & $2.57(1963-2013)$ & 74.4 (2012) & 1.59 (1974) \\
\hline Chorniava & Lyubkivtsi village & $1.67(1985-2013)$ & $85.1(1996)$ & $1.21(1991)$ \\
\hline Latorytsya & Mukachevo town & $26.4(1962-2013)$ & $1480(1958)$ & $64.1(1972)$ \\
\hline Latorytsya & Pidpolozzia village & $9.27(1947-2013)$ & $537(1958)$ & $44.2(2003)$ \\
\hline Latorytsya & Svaliava town & $14.7(1962-2013)$ & $540(1967)$ & $34.4(1973)$ \\
\hline Latorytsya & Chop town & $35.9(1957-2013)$ & $653(1968)$ & $66.5(2015)$ \\
\hline Vicha & Nelipyne village & $6.87(1958-2013)$ & 249 (1958) & $18.6(1973)$ \\
\hline Stara & Zniatseve village & $2.27(1952-2013)$ & $54.7(1974)$ & $9.0(2014)$ \\
\hline Uzh & Uzhhorod city & $29.3(1947-2013)$ & $1680(1958)$ & $108(1973)$ \\
\hline Uzh & Zhornava village & $6.63(1952-2013)$ & $284(1958)$ & $30.9(1961)$ \\
\hline Uzh & Zaricheve village & $21.0(1947-2013)$ & $1210(1958)$ & $92.8(1973)$ \\
\hline Turia & Simer village & $9.26(1958-2013)$ & $427(1958)$ & $22.8(1973)$ \\
\hline Rika & Verhnii Bystryi village & $4.17(1954-2013)$ & $142(1958)$ & $16.2(2003)$ \\
\hline Rika & Mizhhiria village & $13.7(1946-2013)$ & 735 (1958) & $54(1946)$ \\
\hline Holiatynka & Maidan village & $2.16(1956-2013)$ & $100(1958)$ & $7.87(1961)$ \\
\hline Pylypets & Pylypets village & $1.44(1958-2013)$ & $57.1(1958)$ & $4.74(2003)$ \\
\hline Studenyi & Nyzhnii Studenyi village & $0.61(1954-2013)$ & $62.6(1986)$ & $1.54(1961)$ \\
\hline
\end{tabular}

determined, because they have several full cycles of fluctuations. The duration of the cycles on their tributaries and the Siret River will be specified with the extension of the observation series, because such data have incomplete increase and decrease phases of long-term cyclic fluctuations. The observation series of the maximum flow of snow-rain floods in the Danube Basin within Ukraine are characterised by synchronous fluctuations, which do not always have synchronous phases. In general, the maximum runoff of the cold period over the past 10 years was characterised by fluctuation and has a decreasing trend at most of the study gauges. Some hydrological stations are an exception. Because the results of the analysis of changes of river flow depend on the availability and length of long-term data series, there is a need to continuously carry out estimation of the long-term cyclical fluctuations of the maximum runoff of rivers. This will allow the discovery of new tendencies in fluctuations and the making of forecasts for the future, because the Danube River Basin within Ukraine is characterised by dangerous flood activity. 
Bibliography

2000/60/EC, Directive of the European Parliament and of the Council of 23 October 2000 establishing a framework for Community action in the field of water policy, EUR-Lex

Andreyanov V.G., 1959, Cyclical fluctuations of annual runoff and their account at hydrological calculations, (in Russian), Proceedings of Russian State Hydrological Institute, 68, 3-49

Bauzha T., Gorbachova L., 2017, The features of the cyclical fluctuations, homogeneity and stationarity of the average annual flow of the Southern Buh River Basin, Annals of Valahia University of Targoviste. Geographical Series, 17 (1), 5-17, DOI: 10.1515/avutgs-2017-0001

Boiko V., Kulbida M., 2001, Hydrological analysis of high snow-rain flood in Transcarpathia in March 2001 and problems of operational forecasting, (in Ukrainian), Hydrology, Hydrochemistry and Hydroecology, 2, 272-278

Chow V.T., Maidment D.R., Mays L.W., 1988, Applied hydrology, McGraw-Hill, 572 pp.

Gâştescu P., Ţuchiu E., 2012, The Danube River in the Pontic sector - hydrological regime, [in:] Water resource and wetlands. Conference Proceedings, P. Gâştescu, W. Lewis Jr., P. Breţcan (eds.), Tulcea, Romania, 13-26

Gorbachova L., 2014, Methodical approaches the assessment of the homogeneity and stationarity of hydrological observation series, (in Ukrainian), Hydrology, Hydrochemistry and Hydroecology, 5 (32), 22-31

Gorbachova L., 2015, Place and role of hydro-genetic analysis among modern research methods runoff, (in Ukrainian), Proceedings of Ukrainian Hydrometeorological Institute, 268, $73-81$

Gorbachova L., Bauzha T.O., 2012, The reasons of the instationarity of the seasonal runoff of rivers and streams in the Rika River basin, [in:] Water resource and wetlands. Conference Proceedings, P. Gâştescu, W. Lewis Jr., P. Breţcan (eds.), Tulcea, Romania, 209-214

Gorbachova L., Bauzha T., 2013, Complex analysis of stationarity and homogeneity of flash flood maximum discharges in the Rika River basin, Energetika, 59 (3), 167-174, DOI: 10.6001/energetika.v59i3.2708

Gorbachova L., Khrystyuk B., 2014, Hydro-genetic methods of the analysis of the average annual runoff in the Danube basin, [in:] Proceeding of the XXVI conference of the Danubian countries on hydrological forecasting and hydrological bases of water management. Bridging the sciences - crossing borders, 22-24 September 2014, Deggendorf, Germany, 71-74 Hall J., Arheimer B., Aronica G.T., Bilibashi A., Boháč M., Bonacci O., Borg, M., Burlando P., Castellarin A., Chirico G.B., Claps P., Fiala K., Gaál L., Gorbachova L., Gül A., Hannaford J., Kiss A., Kjeldsen T., Kohnová S., Koskela J.J., Macdonald N., Mavrova-Guirguinova M., Ledvinka O., Mediero L., Merz B., Merz R., Molnar P., Montanari A., Osuch M., Parajka J., Perdigão R.A.P., Radevski I., Renard B., Rogger M., Salinas J.L., Sauquet E., Šraj M., Szolgay J., Viglione A., Volpi E., Wilson D., Zaimi K., Blöschl G., 2015, A European Flood Database: facilitating comprehensive flood research beyond administrative boundaries, Proceedings of the International Association of Hydrological Sciences, 370, 89-95, DOI: 10.5194/piahs-370-89-2015

Merriam C.F., 1937, A comprehensive study of the rainfall on the Susquehanna Valley, Transactions American Geophysical Union, 18 (2), 471-476

Kosovets O.O., Kulbida M.I., Babichenko V.M. (eds.), 2005, Climatic Cadastre of Ukraine, (in Ukrainian), Central Geophysical Observatory, 85-104

Pekarova, P., Miklanek, P., Pekar, J., 2003, Spatial and temporal runoff oscillation analysis of the main rivers of the world during the 19th-20th centuries. Journal of Hydrology, 274, 62-79, DOI: 10.1016/S0022-1694(02)00397-9.

Pekarova P., Miklanek P., Melo M., Halmova D., Pekar J., Bacova Mitkova V., 2014, Flood marks along the Danube River between Passau and Bratislav, Veda, Slovak Committee for Hydrology, Bratislava, 102 pp.

Rippl W., 1883, The capacity of storage reservoirs for water supply, Proceedings of the Institute of Civil Engineers, 71, 270-278. DOI: 10.1680/imotp.1883.21797

Searcy J.K., Hardison H.C., 1960, Double-mass curves. Manual of hydrology: Part 1. General surface-water techniques, Geological Survey Water-Supply Paper 1541-B, United States Government Printing Office, 36 pp.

Susidko M.M., Luk'yanets O.I., 2009, The Carpathians - flood danger region of Ukraine. Basin runoff forecasting system in Zakarpattya: methodical and technological basis of its components, Nika-Centre, Kyiv, 88 pp.

WMO, 2009, Guide to hydrological practices. Volume II: Management of water resources and application of hydrological practices, WMO-No. 168, World Meteorological Organization, Geneva 